\title{
O FUTURO DA REPRESENTAÇÃO: NOTA INTRODUTÓRIA
}

Adrián Gurza Lavalle

Cicero Araujo

A representação política - sua reconfiguração e alargamento - tornou-se tema emergente do debate na teoria democrática e na filosofia política normativa na última década. Há motivos para tanto. Primeiro, a crise do Estado de bemestar e o abandono do desenvolvimentismo no plano das políticas econômicas erodiu os pressupostos distributivistas que acompanharam a construção da democracia de massas. De modo concomitante, as agudas transformações do mercado de trabalho, isto é, a informalização infrene e a precarização, minaram as clivagens "estruturais" que alicerçaram tanto a edificação do sindicalismo como expediente da representação funcional de interesses quanto os partidos de massas como expressão política por excelência dessas clivagens. Partidos políticos desempenham cada vez menos funções de ordenação estável das preferências do eleitorado e têm visto suas funções de intermediação entre políticos e eleitores serem progressivamente absorvidas pelos meios massivos de comunicação. De fato, os diagnósticos sobre a personalização da política graças à mídia são uma constante na literatura dedicada à análise dos processos de reconfiguração da representação. 
Segundo, em inúmeros países está se vivenciando uma abertura do poder executivo à participação de atores societários investidos juridicamente como representantes de determinados segmentos e interesses da população no desenho, implementação e supervisão de políticas públicas. De modo semelhante àquilo que aconteceu nas primeiras décadas do século XX, quando as instituições da representação política foram alargadas junto com a própria democracia mediante a emergência dos partidos de massa, esses processos de reconfiguração da representação englobando o poder executivo podem confluir para uma nova ampliação da democracia.

O dossiê apresentado neste número da Lua Nova não apenas obedece à intenção de atentar para a atualidade do tema, mas, sobretudo, constitui um esforço de mostrar os principais deslocamentos postos hoje no debate como indícios a apontarem para o futuro da representação política nas democracias. Procuramos unir neste dossiê tanto contri10 buições nacionais quanto contribuições de autores internacionais que se destacam no assunto, algumas já publicadas em língua inglesa na forma de artigo ou capítulo de livro e que foram traduzidas para esta edição mediante autorização generosa de editores e autores.

Hanna Pitkin, em argumento reconstrutivo baseado em abordagem própria à filosofia da linguagem, lança mão das transformações seculares nos usos da fala, nas cristalizações ideológicas no plano da filosofia política e nas práticas históricas de representação política para mostrar a emergência das feições distintivas da representação moderna. Além do esplêndido trabalho de reconstrução da gênese da representação, o texto presta o valioso serviço de mostrar como, no mundo moderno, a idéia da representação simbólica de valores ou entidades alegóricas e por forças abstratas da unidade do corpo político fora muito tardiamente substituída pela idéia de representação de indivíduos e interesses particulares, própria da tradição liberal. 
O trabalho de Adrián Gurza Lavalle, Peter Houtzager e Graziela Castello desenvolve um balanço das literaturas que estudam tanto transformações recentes da representação política quanto inovações institucionais de aprofundamento da democracia, apontando as limitações de ambas para extrair as conseqüências dessas transformações para uma agenda de reforma da democracia. Sustenta-se que a existência de processos de diversificação do lócus da representação e de pluralização dos atores com investidura para exercê-la tem multiplicado práticas inéditas de representação propriamente política no seio da sociedade civil, cuja compreensão cabal, do ponto de vista dos seus eventuais efeitos negativos ou positivos sobre a qualidade da democracia, requer uma revisão e reespecificação dos pressupostos que alicerçam a nossa compreensão da representação política. Enseja-se, nesse sentido, o resgate crítico da categoria "representação virtual”, cunhada por Edmund Burke, como expediente que insinua um horizonte analítico sugestivo para reelaborar a relação entre aprofundamento da democracia e representação política.

$\mathrm{O}$ artigo de Manin, Przeworski e Stokes analisa a relação entre eleições e representação ou, com maior precisão, visa a indagar o quanto o mecanismo eleitoral pode, de fato, tornar mais representativas as instituições da democracia. Mesmo do ponto de vista de uma compreensão minimalista da democracia, como aquela característica dos autores, diagnosticam-se sérias limitações no voto como mecanismo capaz de alavancar algum controle do representado sobre o representante. Contudo, os autores vão além dessa constatação persuasiva e abrem um horizonte amplo de exploração ao admitir que eleições não são o único mecanismo em condições de promover representação, apontando para algumas feições institucionais do sistema político. O marco para se pensar na questão da representatividade é assim alargado, embora permaneça, no fundamental, restrito 
às balizas do sistema político e da compreensão liberal da representação.

O texto de Iris Young examina os dilemas de inclusão enfrentados pela democracia e desenvolve um modelo analítico instigante para se pensar na representação de minorias em termos plenamente compatíveis com exigências universalistas inerentes à cidadania e democracia modernas. Isto, contornando as críticas que acusam o essencialismo ou naturalismo das chamadas políticas da diferença ou centradas em identidades. Para equacionar um modelo de representação reconciliável com os reclamos das identidades, a autora alarga a compreensão da representação quanto àquilo que é passível de ser representado. É claro que a representação diz respeito a interesses, mas não só; também é possível representar opiniões e perspectivas. A compreensão liberal da democracia é assim alargada, embora o lócus da representação continue, no fundamental, restrito ao parlamento.

12 O artigo de Nadia Urbinati faz uma reflexão sobre a natureza da representação democrática, mostrando sua originalidade como forma de governo representativo. Seu esforço teórico, nesse sentido, é apontar as diferenças desse modelo em relação à "democracia eleitoral”, por um lado, e à "democracia direta”, por outro. Seguindo caminho trilhado por Bernard Manin, entre outros, mas introduzindo suas próprias inquietações, Urbinati faz preciosas indicações sobre como um certo modo canônico de ver a soberania popular poderia ser revisado a partir da idéia de representação defendida no artigo. O que emerge da sua reflexão é que a democracia representativa é não só uma forma diferenciada de participação, mas superior às suas supostas concorrentes.

Já o artigo de Cicero Araujo pretende se valer de duas metáforas artísticas, a fim de explorar um contraste entre modos de pensar a representação política. A idéia é associar a noção de "soberania estatal", com seu modo peculiar de 
elaborar a representação, à metáfora plástica (o "retrato”), e a noção de "constituição mista" à metáfora teatral (o "drama”). São, do ponto de vista do autor, idealizações muito diferentes da boa ordem política, ainda que no vocabulário político tradicional seja costume confundi-las, produzindo seus próprios impactos a respeito do que esperar das práticas de representação das autoridades políticas.

Por fim, gostaríamos de ressaltar que o título deste dossiê, "O Futuro da Representação", tem o propósito de sugerir que a representação, em suas diferentes formas, é e continuará sendo um recurso crucial da atividade política. Embora passando por fundas transformações e colocando em causa as formas de representação típicas dos últimos cem anos, como alguns dos artigos aqui publicados indicam, as sociedades contemporâneas, inclusive a brasileira, têm mostrado enorme versatilidade no sentido de construir modos alternativos, inéditos e até mesmo inesperados de representação. Em suma, ainda que essa perspectiva editorial não tenha sido explicitamente visada pelos autores, o que acaba sobressaindo de sua leitura é que, sem desprezar a avaliação crítica e a inquietação sobre o futuro que elaboram, os sinais de declínio da tradição não podem ser confundidos com o declínio da própria idéia de representação. 